Dawid SZPAK, Janusz R. RAK, Krzysztof BORYCZKO, Izabela PIEGDOŃ, Jakub ŻYWIEC

Rzeszow University of Technology (Politechnika Rzeszowska)

\title{
RISK ASSESSMENT FOR THE SELECTED SURFACE WATER INTAKE
}

\section{Ocena ryzyka zagrożeń dla wybranego ujęcia wody powierzchniowej}

\begin{abstract}
The purpose of the work is to analyze the risk for surface water intake, taking into account factors affecting the water quality. A three-parameter risk definition was proposed. It was found that the analyzed water intake has an efficient system that protects consumers against drinking water of inadequate quality (multibarier system). The task of the water supply company is to maintain its security measures (including a caution and warning station, biomonitoring) in a state of efficiency.
\end{abstract}

Keywords: risk, surface water intake

Streszczenie: W pracy przeprowadzono analize ryzyka dla ujęcia wody powierzchniowej z uwzględnieniem czynników negatywnie wptywajacych na jakość ujmowanej wody. Zaproponowano trójparametryczna definicję ryzyka. Stwierdzono, że analizowane ujęcie wody posiada sprawny system zabezpieczajacy konsumentów przed spożyciem wody o nieodpowiedniej jakości (system multibariera). Zadaniem przedsiębiorstwa wodociagowego jest utrzymywanie posiadanych środków bezpieczeństwa (m.in. stacja osłonowo-ostrzegawcza, biomonitoring) $w$ stanie zdatności.

Słowa kluczowe: ryzyko, ujęcie wody powierzchniowej 


\section{Introduction}

The Water Law Act of 20 July 2017 [8] established the need to carry out the so-called risk analysis including risk assessment for abstracted water in order to designate an indirect protection zone for water intake. Risk analysis should be carried out for water intakes supplying more than $10 \mathrm{~m}^{3} / \mathrm{d}$ or delivering water for more than 50 people. Lack of risk analysis may result in withdrawal of water law permit for water abstraction. Risk analysis for water intakes introduced by the Water Law Act of 20 July 2017 [8] may constitute one of the stages of the Water Safety Plan (WSP) recommended by the World Health Organization (WHO) and is in line with current standards regarding safe delivery of water for consumption $[9,11]$.

The purpose of the work is to assessment the risk for surface water intake, taking into account factors negatively affecting the quality of abstracted water. The risk assessment for water intakes can be performed based on the proposed three-stage risk matrix. This work may provide a substantive basis for water supply companies. Risk analysis is a procedure that involves identifying hazards, estimating the likelihood of a threat, estimating vulnerability to threat and determining the consequences of an event [12]. As risk analysis for water intakes became obligatory in Poland only under the Act [8], no criteria and methods of risk assessment have been developed so far and only single studies in this area have been done [1]. The paper presents a three-stage risk matrix that was used to assess the risk for surface water intake for a selected city.

\section{Research methodology}

In environmental engineering (as in most engineering applications), applies the basic definition of risk, which presents risk as the product of the probability of occurrence of undesirable events and losses resulting from their occurrence. This definition is a starting point and can be extended with additional variables, primarily taking into account the degree of protection of water consumers against the consequences of undesirable events. Advanced works on the use of matrix methods in the risk analysis of municipal systems were carried out at the Department of Water Supply and Sewage Disposal at the Rzeszów University of Technology under the supervision of Professor Janusz Rak. These works led to the development of expanded risk assessment methods described in detail in numerous publications and monographs [4,6]. The developed risk matrices can be modified depending on the specifics of the Collective Water Supply System (CWSS) and the purpose of risk analysis. Currently, research on the safety of water supply is often focused on the search for unconventional methods of risk analysis allowing to eliminate the limitations of the matrix method $[2,5,7]$. 
A three-stage risk matrix is proposed for this risk analysis. Risk is a function of three parameters $r=f(P, C, O)$. The risk value is directly proportional to parameters $P$ and $C$, while it is inversely proportional to the parameter $\mathrm{O}[4]$ :

$$
r=\frac{P \cdot C}{O}
$$

where:

$P$ - the probability of occurrence of the i-th threat,

$C$ - the consequences for water consumers as a result of the occurrence of the i-th threat,

$O$ - the level of trust in the effectiveness of safety system components, which are to ensure the water supply of appropriate quality to consumers after the occurrence of the i-th threat.

Each time for the variables $P, C$ and $O$ the size level is assumed by means of a point scale from 1 to 5, using the three- stage matrix method. The risk ranges from [0.20-25]. Table 1 proposes a method of adopting weights of risk variables. Table 2 proposes criteria for assessing the risk.

Table 1

\section{Risk weights}

\begin{tabular}{|c|c|c|c||}
\hline Probability (P) & Effects (C) & Security (O) & Point weight \\
\hline very low & very low & very low & 1 \\
\hline low & low & low & 2 \\
\hline average & average & average & 3 \\
\hline high & high & high & 4 \\
\hline very high & very high & very high & 5 \\
\hline
\end{tabular}

Table 2

\section{Criteria for risk assessment}

\begin{tabular}{|c|c|}
\hline Risk category & Value of the risk \\
\hline tolerable & $0,20 \leq \mathrm{r} \leq 5,0$ \\
\hline controlled & $5,0<\mathrm{r} \leq 9,0$ \\
\hline unacceptable & $9,0<\mathrm{r} \leq 25,0$ \\
\hline
\end{tabular}

\section{Research object}

The analysis was carried out for a voivodship city located in south-eastern Poland. The city is supplied with water from the Water Treatment Plant (WTP). The source of water for 
WTP are the surface waters of the Wisłok River, partitioned by a water threshold for raising and stabilizing the water level necessary for the proper operation of the intake. Water is drawn from the intake ZUW II, while the intake ZUW I is a reserve.

The currently used technological process of water treatment includes the following stages of treatment:

- surface intake on the Wisłok river - suction sieves,

- initial oxidation with ozone - the so-called preliminary ozonation (only ZUW II),

- coagulation using aluminum compounds,

- sedimentation in horizontal settling tanks,

- filtration through a sand bed (ZUW I) or filtration through an anthracite-sand bed (ZUW II),

- indirect ozonation,

- filtration through an activated carbon bed,

- preliminary disinfection with UV lamps,

- disinfection with chlorine compounds: chlorine dioxide and chlorine gas,

- water $\mathrm{pH}$ correction station with sodium carbonate.

The detailed state of the current land development of the location of the analysed surface water intake was determined on the basis of information obtained from the water supply company and a local vision carried out in October 2019. The devices for abstracting, treating and pumping water are located on the left bank of the Wisłok River. The water supply company currently produces water in the amount of about 13 to 14 million $\mathrm{m}^{3} /$ year, which is less than $50 \%$ of the amount of water for which the plant received a water law permit.

The diversification index of water intakes was determined for the analysed city [3]. The water supply system of the analysed city was classified (taking into account the "small" intakes maintained by the water supply company) in the category of medium diversification. It should be noted, however, that both the intakes of ZUW I and ZUW II abstract water from the Wisłok River and there is a distance of several dozen meters between them. For this reason, it is very important to establish cooperation with neighbouring municipalities in order to connect neighbouring water intakes with the analysed water supply network, and thus to increase the safety of water supply to consumers, especially during a crisis.

\section{Identification of sources of threat}

One of the main factors affecting the content of organic and inorganic compounds in surface waters are physical-geographical and climatic factors, as well as anthropogenic conditions occurring in the catchment area, including, in particular, the manner of land use. Nitrogen and phosphorus compounds from point and area potential sources of pollution are particularly dangerous for the aquatic environment. These compounds enrich the aquatic environment with nutrients, responsible for the phenomenon of eutrophication of waters, causing the development of algae and cyanobacteria, which results in increased water 
turbidity and reduced ichthyofauna. According to the data contained in [10] in the catchment area of the Wisłok river, above the water intake, 22 point municipal pollution, 8 point sources of industrial pollution and 3 plants with a high and increased risk of a serious failure were identified. In the area of indirect protection of water intake there is one discharge of municipal sewage.

The identification of linear threats was based on the analysis of the communication system within the indirect protection zone of the water intake for the city covered by the analysis. In the indirect protection zone there is a national road No. 19, which is part of the international route E371 and a railway line. However, the threat to the water intake quality results from the fact that this road and the railway line pass through the Wisłok tributaries within the indirect protection zone. The analysis also took into account local roads running in the indirect protection zone of the water intake for the analysed city and passing through the tributaries of the Wisłok River. In case of a crisis, the water supply company has its own sleeves to protect against spreading. This barrier is unfolded immediately before the water intake and complements the activities carried out by the units of the State Fire Service.

As mentioned at the beginning of the chapter, the source of the threat to good water status in the Podkarpackie Voivodeship is the occurrence of eutrophication in waters caused by pollution from municipal sources. Agricultural land in the indirect protection area accounts for about $50 \%$ of the surface of the indirect protection zone of the water intake covered by the analysis. For this reason, the use of artificial fertilization and chemical plant protection products in case of intense rainfall may cause the penetration of pollutants by leaching from the soil to surrounding watercourses and further to Wisłok. Therefore, restrictions on the use of chemical plant protection products for environmentally friendly biopreparations should be considered. Another the source of the threat to water quality is the discharge of untreated wastewater into the soil or into the water through the discharge of wastewater into roadside ditches, leaks from leaking septic tanks and waste disposal on fields. When introducing untreated sanitary sewage into surface waters, there is an increase in suspended solids, nitrogen and phosphorus compounds, chlorides, dissolved substances, $\mathrm{BZT}_{5}$, reduction of dissolved oxygen and significant biological contamination. The organization of wastewater management (which is the responsibility of local government units) is therefore a very important aspect of water quality protection in the Wisłok river basin and in the indirect protection zone of the water intake covered by the analysis.

The register of major failures occurring in the area covered by the analysis in 1998-2013 was also analysed. None of the events with major failure in the analysed period occurred in the catchment area of the Wisłok above the water intake covered by the analysis.

The key to reducing the risk of delivering water of inadequate quality to consumers is the so-called multibarier system, i.e. a complicated system of complementary security. The multibarier in the water supply system of the analysed city includes the following risk reduction measures (barriers).

- late warning system - monitoring the quality of taken up water in the water distribution subsystem (PsDyW),

- sanitary protection of the basin, 
- delayed warning system - water quality monitoring carried out on the intake and during treatment,

- closing the intake and use of water accumulated in the clean water tanks in the WTP,

- use of water accumulated in the network water tanks,

- starting water supply from alternative sources,

- biomonitoring based on indicator organisms (mussels),

- early warning system using a protection and warning station.

\section{Risk analysis results}

A detailed risk analysis has enabled the identification of events that pose the greatest threat to the quality of water in the source and an assessment of the effectiveness of the safety system components. Undesirable events related to seasonal changes in water quality (water blooms, turbidity, ammonium ion) are the threats with the highest risk. As for catastrophic phenomena, the threat with the highest risk is caused by the failure of the sewage treatment plant (capacity $\mathrm{Q}=700 \mathrm{~m}^{3} / \mathrm{d}$ ) located within the indirect protection zone of the water intake, at a distance of about $4.8 \mathrm{~km}$ from the intake, i.e. below the protection and warning station. The likelihood of such an event is small, but the losses which it may cause require a effective operation of safety system components. Table 3 presents a fragment of the risk analysis carried out.

The water supply company has the CWSS well-protected against factors adversely affecting the quality of the water taken up, therefore the risk for the analysed undesirable events was assessed as tolerable. Therefore, it is proposed to leave the range of direct and indirect protection zone of the water intake unchanged.

Risk assessment is a continuous process, that is why, based on the performed risk analysis, a proposal of corrective or repair actions that the water supply company should take in order to constantly control and reduce the risk, was presented.

Corrective actions have been presented for for the sources of threats that have the most significant impact on the risk levels:

- developing procedures for dealing with contaminants that conventional treatment will not be able to remove,

- obtaining funds by local government units for the construction of a sanitary sewage system in towns located within the Wisłok river basin, in particular in the indirect protection zone of the water intake,

- monitoring the usage of plant protection products in the indirect protection area and controlling their quality,

- development of a plan for checking the technical condition of facilities and pipelines at sewage treatment plants and procedures in case of a major failure in sewage treatment plants located in the Wisłok river basin. 
Table 3

Fragment of the risk analysis for the selected water intake

\begin{tabular}{|c|c|c|}
\hline$=$ & $\stackrel{\infty}{\infty}$ & $\nabla$ \\
\hline 0 & in & $\forall$ \\
\hline 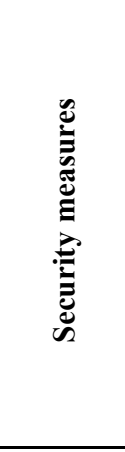 & 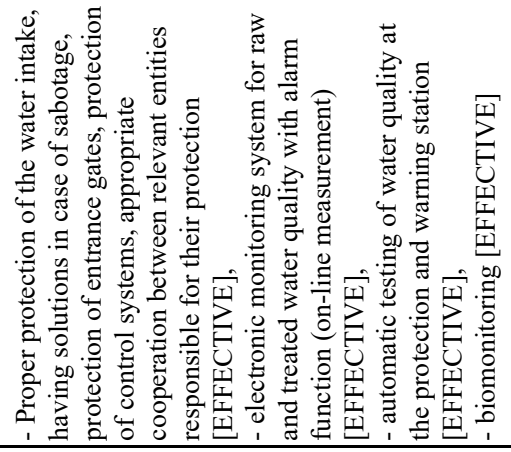 & 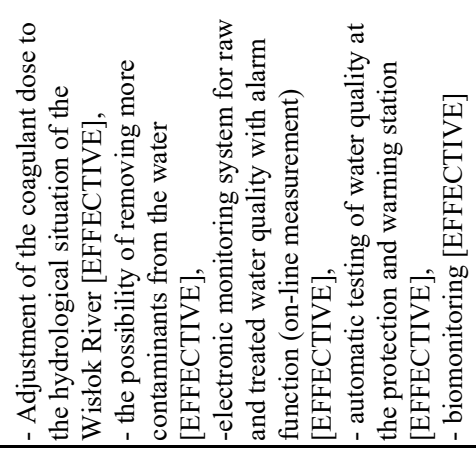 \\
\hline$A$ & - & $\nabla$ \\
\hline$\cup$ & $\nabla$ & $\nabla$ \\
\hline 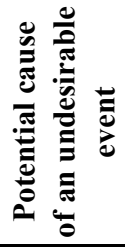 & 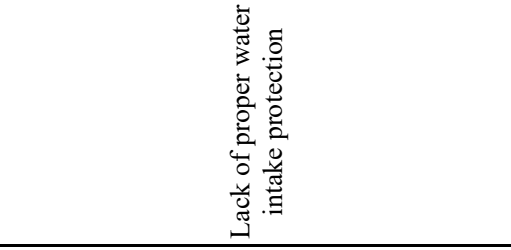 & 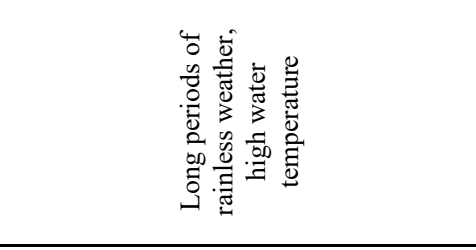 \\
\hline 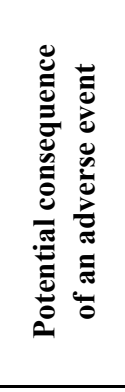 & 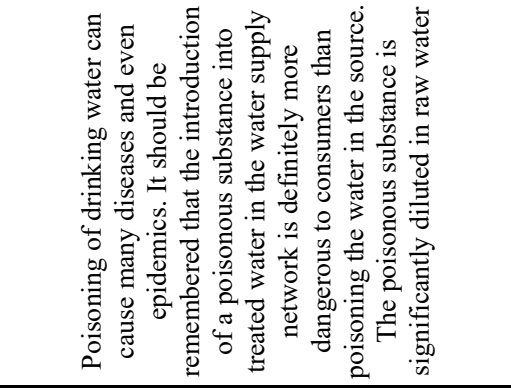 & 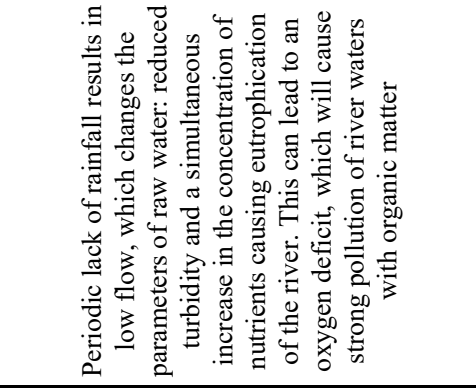 \\
\hline 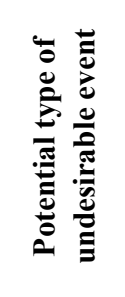 & 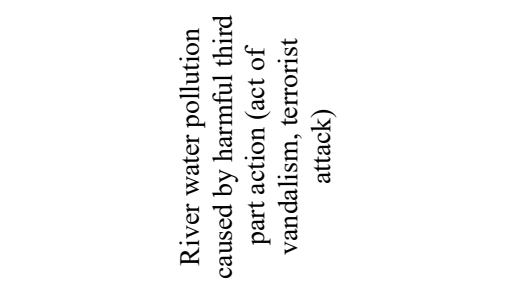 & 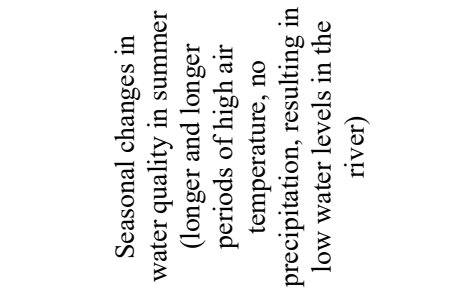 \\
\hline$\stackrel{1}{5}$ & - & $N$ \\
\hline
\end{tabular}




\section{Conclusions}

The risk analysis for water intakes should be the guarantor of making the right operational decisions regarding the selection of the best technical, economic and operational solutions.

The analysed system of collective water supply is equipped with necessary protection related to the water intake from the Wisłok River. Assessment of the risk of water intake threats did not reveal any significant threats for tap water consumers. The methodology presented in the work can be used by the water supply company for annual evaluation of water intake threats, as the risk factors cannot be completely eliminated.

It is proposed to leave the range of direct and indirect protection zone of the water intake unchanged. The conducted risk analysis, including the assessment of health hazards, taking into account factors negatively affecting the quality of the taken water, has shown that the current zone of direct and indirect protection of water intake is sufficient, but also necessary to meet the goal of supplying consumers with water in the required quantity and pressure and continuous and reliable way, as well as ensuring the proper quality of water supplied.

The long-term strategy for the development of CWSS covered by the analysis should consider the possibility of supplying water to the city from a second (alternative) water intake - start study works.

\section{References}

1. Lidzbarski M.: Analiza ryzyka w procesie ustanawiania strefy ochronnej ujęć wód podziemnych „Osowa” i „Dolina Radości” w Gdańsku. Biuletyn Państwowego Instytutu Geologicznego, vol. 475, Warszawa 2019.

2. Piegdon I., Tchórzewska-Cieślak B.: The Use of Fuzzy Set Theory in Exploitation Management Process on the Water Supply Network. Journal of Konbin, No 3(35), Warszawa 2015, DOI 10.1515/jok-2015-0044.

3. Rak J., Boryczko K.: Assessment of water supply diversification using the Pielou index. Environmental Engineering V - Proceedings of the 5th National Congress of Environmental Engineering, Lublin 2017.

4. Rak J., Tchórzewska-Cieślak B.: Ryzyko w eksploatacji systemów zaopatrzenia w wodę. Wydawnictwo Seidel-Przywecki Sp. z o.o., Józefosław 2013.

5. Rak J., Żywiec J.: Selected Aspects of the Water Supply System Safety. Lecture Notes in Civil Engineering, vol. 47, 2020.

6. Rak. J., Tchórzewska-Cieślak B., Boryczko K., Szpak D.: Wykorzystanie zaawansowanych metod matrycowych w analizie ryzyka w systemach zbiorowego zaopatrzenia w wodę. Gaz, Woda i Technika Sanitarna, nr 11, Warszawa 2017. 
7. Szpak D., Tchórzewska-Cieślak B.: The Use of Grey Systems Theory to Analyze the Water Supply Systems Safety. Water Resources Management, vol. 33, 2019.

8. Ustawa z dnia 20 lipca 2017 r. - Prawo wodne (Dz.U. 2017 poz. 1566 wraz z poźniejszymi zmianami).

9. Water safety plan manual: step-by-step risk management for drinking-water suppliers. WHO, Geneva 2009.

10. WIOŚ Rzeszów: Wody powierzchniowe województwa podkarpackiego. Identyfikacja wybranych zagrożeń. Rzeszów 2016.

11. Wniosek Dyrektywa Parlamentu Europejskiego i Rady w sprawie jakości wody przeznaczonej do spożycia przez ludzi (wersja przekształcona) z dnia 1.2.2018 r.

12. Zimoch I., Kuśnierski A.: Exploitation safety of water supply systems in areas used for agriculture. WIT Transactions on Ecology and the Environment, vol. 220, 2017. 


\section{OCENA RYZYKA ZAGROŻEŃ DLA WYBRANEGO UJECIA WODY POWIERZCHNIOWEJ}

\section{Wprowadzenie}

Ustawa Prawo Wodne z dnia 20 lipca 2017 r. [8] ustanowiła konieczność przeprowadzenia tzw. analizy ryzyka obejmującej ocenę zagrożeń dla ujmowanej wody w celu wyznaczenia strefy ochrony pośredniej ujęcia wody. Analizę należy przeprowadzić dla ujęć wody, dostarczających więcej niż $10 \mathrm{~m}^{3} / \mathrm{d}$ lub służących zaopatrzeniu w wodę więcej niż 50 osób. Brak takiego działania może skutkować cofnięciem pozwolenia wodnoprawnego na pobór wody. Analiza ryzyka dla ujęć wody wprowadzona przez ustawę [8] może stanowić jeden z etapów Planu Bezpieczeństwa Wodnego (PBW) zalecanego przez Światową Organizację Zdrowia (WHO) i wpisuje się w aktualne standardy, które dotyczą bezpieczeństwa dostawy wody przeznaczonej do spożycia [9,11].

Celem pracy jest ocena ryzyka dla ujęcia wody powierzchniowej z uwzględnieniem czynników negatywnie wpływających na jakość ujmowanej wody. Ocenę ryzyka dla ujęć wody można wykonać, opierając się na zaproponowanej matrycy trójstopniowej. Niniejsza praca może stanowić podstawę merytoryczną dla przedsiębiorstw wodociągowych. Analiza ryzyka jest to procedura polegająca na identyfikowaniu zagrożeń, szacowaniu prawdopodobieństwa powstania zagrożenia, szacowaniu podatności na zagrożenie oraz określaniu skutków zdarzenia [12]. Ponieważ analiza ryzyka dla ujęć wody stała się w Polsce obligatoryjna dopiero na mocy ustawy [8], nie ma dotychczas wypracowanych kryteriów oraz sposobów oceny zagrożeń i na razie zostały wykonane jedynie pojedyncze opracowania w tym zakresie [1]. W pracy została przedstawiona trójstopniowa matryca ryzyka, która została wykorzystana do oceny ryzyka dla ujęcia wody powierzchniowej dla wybranego miasta.

\section{Metodyka badań}

W inżynierii środowiska (podobnie jak w większości zastosowań inżynierskich) obowiązuje podstawowa definicja ryzyka, która przedstawia ryzyko, jako iloczyn prawdopodobieństwa zajścia zdarzeń niepożądanych i strat powstałych w wyniku ich zajścia. Definicja ta stanowi punkt wyjścia i może zostać rozbudowana o dodatkowe zmienne, przede wszystkim uwzględniające stopień zabezpieczenia konsumentów wody przed skutkami zdarzeń niepożądanych. Zaawansowane prace, dotyczące wykorzystania metod matrycowych w analizie ryzyka systemów komunalnych były prowadzone w Katedrze Zaopatrzenia 
w Wodę i Odprowadzania Ścieków Politechniki Rzeszowskiej pod kierunkiem prof. Janusza Raka. Doprowadziło to do opracowania rozbudowanych metod oceny ryzyka szczegółowo opisanych w licznych publikacjach oraz monografiach [4,6]. Przygotowane matryce ryzyka mogą być modyfikowane w zależności od specyfiki systemu zbiorowego zaopatrzenia w wodę (SZZW) oraz celu analizy ryzyka. Obecnie badania, które dotyczą bezpieczeństwa dostawy wody często ukierunkowane są na poszukiwanie niekonwencjonalnych metod analizy ryzyka, pozwalających na wyeliminowanie ograniczeń metody matrycowej $[2,5,7]$.

Do przedmiotowej analizy ryzyka proponuje się wykorzystanie trójstopniowej matrycy ryzyka. Ryzyko jest funkcją trzech zmiennych $r=f(P, C, O)$. Ryzyko jest wprost proporcjonalne do wartości zmiennych $\mathrm{P}$ i $\mathrm{C}$ oraz odwrotnie proporcjonalne do wartości zniennej $O$ [4]:

$$
r=\frac{P \cdot C}{O}
$$

gdzie:

$P \quad$ - prawdopodobieństwo wystąpienia $i$-tego zagrożenia,

$C$ - skutki dla konsumentów wody w wyniku zaistnienia $i$-tego zagrożenia,

$O$ - poziom zaufania do skuteczności działania elementów systemów bezpieczeństwa mających zapewniać dostarczanie konsumentom odpowiedniej jakości wody po zaistnieniu $i$-tego zagrożenia.

Każdorazowo dla zmiennych $P, C$ oraz $O$ przyjmuje się wagę w zakresie od 1 do 5 wykorzystując trójstopniową metodę matrycową. Ryzyko przyjmuje wartości z zakresu [0,20-25]. W tabeli 1 zaproponowano sposób przyjmowania wag zmiennych ryzyka. W tabeli 2 zaproponowano kryteria dla oceny ryzyka.

Tabela 1

\section{Wagi zmiennych ryzyka}

\begin{tabular}{||c|c|c|c||}
\hline Prawdopodobieństwo (P) & Skutki (C) & Ochrona (O) & Waga \\
\hline bardzo małe & bardzo małe & bardzo niska & 1 \\
\hline małe & małe & niska & 2 \\
\hline przeciętne & przeciętne & przeciętna & 3 \\
\hline duże & duże & wysoka & 4 \\
\hline bardzo duże & bardzo duże & bardzo wysoka & 5 \\
\hline
\end{tabular}


Tabela 2

Kryteria dla oceny ryzyka

\begin{tabular}{|c|c|}
\hline Kategoria ryzyka & Wartość ryzyka \\
\hline tolerowane & $0,20 \leq \mathrm{r} \leq 5,0$ \\
\hline kontrolowane & $5,0<\mathrm{r} \leq 9,0$ \\
\hline nieakceptowalne & $9,0<\mathrm{r} \leq 25,0$ \\
\hline
\end{tabular}

\section{Obiekt badań}

Analizę przeprowadzono dla miasta wojewódzkiego położonego w południowowschodniej Polsce. Źródłem wody dla zakładu uzdatniania wody (ZUW) są wody powierzchniowe rzeki Wisłok, przegrodzonej progiem wodnym dla podniesienia i stabilizacji poziomu wody niezbędnego dla prawidłowej pracy ujęcia. Woda czerpana jest z ujęcia ZUW II, ujęcie ZUW I stanowi rezerwę.

Obecnie stosowany proces technologiczny uzdatniania wody obejmuje następujące etapy uzdatniania:

- ujęcie powierzchniowe na rzece Wisłok - sita ssawne,

- wstępne utlenienie przy pomocy ozonu - tzw. ozonowanie wstępne (tylko ZUW II),

- koagulacja przy użyciu związków glinu,

- sedymentacja w osadnikach poziomych,

- filtracja przez złoże piaskowe (ZUW I) lub filtracja przez złoże antracytowo-piaskowe (ZUW II),

- ozonowanie pośrednie,

- filtracja przez złoże węgla aktywnego,

- dezynfekcja wstępna za pomocą lamp UV,

- dezynfekcja związkami chloru: dwutlenkiem chloru i chlorem gazowym,

- stacja korekty odczynu pH wody za pomocą węglanu sodu.

Szczegółowy stan aktualnego zagospodarowania terenu lokalizacji analizowanego ujęcia wody powierzchniowej ustalono na podstawie informacji uzyskanych od przedsiębiorstwa wodociągowego oraz wizji lokalnej przeprowadzonej w październiku 2019 r. Urządzenia do poboru, uzdatniania oraz pompowania wody znajdują się na lewym brzegu rzeki Wisłok. Przedsiębiorstwo wodociągowe produkuje obecnie wodę w ilości około 13 do $14 \mathrm{mln} \mathrm{m}^{3} /$ rok, co stanowi niecałe 50\% ilości wody, na którą otrzymano pozwolenie wodno prawne.

Dla analizowanego miasta wyznaczono wskaźnik dywersyfikacji ujęć wody [3]. System zaopatrzenia w wodę analizowanego miasta ( $\mathrm{z}$ uwzględnieniem utrzymywanych przez przedsiębiorstwo wodociągowe „małych” ujęć) przypisano do kategorii dywersyfikacji średniej. Należy jednak zwrócić uwagę, że zarówno ujęcie ZUW I oraz ZUW II pobierają 
wodę z rzeki Wisłok i dzieli ich kilkadziesiąt metrów. Z tego względu bardzo istotne jest nawiązanie współpracy z gminami sąsiednimi w celu połączenia sąsiadujących ujęć wody $\mathrm{z}$ analizowaną siecią wodociągową, a tym samym podniesienie bezpieczeństwa dostawy wody do konsumentów, szczególnie w czasie sytuacji kryzysowej.

\section{Identyfikacja źródeł zagrożenia}

Jednymi z głównych czynników mających wpływ na zawartość związków organicznych i nieorganicznych w wodach powierzchniowych są czynniki fizycznogeograficzne oraz klimatyczne, a także uwarunkowania antropogeniczne występujące na obszarze zlewni, w tym przede wszystkim sposób użytkowania terenu. Szczególnie niebezpieczne dla środowiska wodnego są związki azotu i fosforu pochodzące z punktowych i obszarowych, potencjalnych źródeł zanieczyszczeń. Związki te wzbogacają środowisko wodne w substancje biogenne, odpowiedzialne za zjawisko eutrofizacji wód, wywołując rozwój glonów i sinic, czego konsekwencją jest zwiększenie mętności wody i ograniczenie ichtiofauny. Zgodnie $z$ danymi zawartymi w [10] na obszarze zlewni rzeki Wisłok powyżej ujęcia wody zidentyfikowano 22 punktowych zanieczyszczeń komunałnych, 8 punktowych źródeł zanieczyszczeń przemysłowych, 3 zakłady o dużym (ZDR) oraz zwiększonym ryzyku (ZZR) wystąpienia poważnej awarii. Na terenie ochrony pośredniej ujęcia wody ma miejsce jeden zrzut ścieków komunalnych.

Identyfikację źródeł zagrożeń liniowych oparto na analizie układu komunikacyjnego na terenie strefy ochrony pośredniej ujęcia wody dla miasta objętego analizą. W strefie ochrony pośredniej znajduje się droga krajowa nr 19, która jest częścią międzynarodowej trasy E371, a także linia kolejowa. Zagrożenie dla jakości wody ujmowanej wynika jednak z tego, że ta droga oraz linia kolejowa przechodzą przez dopływy Wisłoka na terenie strefy ochrony pośredniej. W analizie uwzględniono również drogi lokalne biegnące w strefie ochrony pośredniej ujęcia wody dla analizowanego miasta i przechodzące przez dopływy rzeki Wisłok. W przypadku wystąpienia sytuacji kryzysowej przedsiębiorstwo wodociągowe dysponuje własnymi rękawami, zabezpieczającymi przed rozprzestrzenianiem się rozlewu. Bariera ta jest rozkładana bezpośrednio przed ujęciem wody i stanowi uzupełnienie działań prowadzonych przez jednostki Państwowej Straży Pożarnej.

Jak wspomniano na początku rozdziału źródłem zagrożenia dla dobrego stanu wód w województwie podkarpackim jest występowanie w wodach zjawiska eutrofizacji wywołanej zanieczyszczeniami pochodzącymi ze źródeł komunalnych. Użytki rolne na terenie ochrony pośredniej stanowią około 50\% powierzchni strefy ochrony pośredniej ujęcia wody objętego analizą. $Z$ tego powodu stosowanie sztucznego nawożenia i chemicznych środków ochrony roślin w przypadku intensywnych opadów deszczu może powodować przedostawanie się zanieczyszczeń poprzez wymywanie z gleby do okolicznych cieków i dalej do Wisłoka. Należy rozważyć zatem wprowadzenie ograniczeń w stosowaniu chemicznych środków ochrony roślin na rzecz przyjaznych dla środowiska naturalnego biopreparatów. Źródłem zagrożenia dla jakości wody jest także odprowadzanie 
ścieków nieoczyszczonych do gleby lub do wody poprzez odprowadzanie ścieków do przydrożnych rowów, przecieki z nieszczelnych szamb, a także wywóz nieczystości na pola. W przypadku wprowadzenia do wód powierzchniowych nieoczyszczonych ścieków sanitarnych następuje wzrost zawiesiny, związków azotu i fosforu, chlorków, substancji rozpuszczonych, $\mathrm{BZT}_{5}$, redukcja tlenu rozpuszczonego oraz znaczne skażenie biologiczne. Uporządkowanie gospodarki ściekowej (leżące w gestii jednostek samorządu terytorialnego) jest zatem bardzo istotnym aspektem ochrony jakości wody w zlewni rzeki Wisłok jak i w strefie ochrony pośredniej ujęcia wody objętego analizą.

Przeanalizowano także rejestr poważnych awarii, które miały miejsce na terenie objętym analizą w latach 1998-2013. Żadne ze zdarzeń o znamionach poważnej awarii w analizowanym okresie nie miało miejsca w zlewni rzeki Wisłok powyżej ujęcia wody objętego analizą.

Kluczowe znaczenie dla zmniejszenia ryzyka dostarczenia do konsumentów wody o nieodpowiedniej jakości ma tzw. system multibariera, czyli skomplikowany system dopełniających się zabezpieczeń. W skład systemu multibariera w SZZW analizowanego miasta wchodzą następujące środki redukcji ryzyka (bariery):

- układ późnego ostrzegania - monitoring jakości wody pobranej w podsystemie dystrybucji wody (PsDyW),

- sanitarna ochrona zlewni,

- układ opóźnionego ostrzegania - monitoring jakości wody prowadzony na ujęciu i podczas uzdatniania,

- zamknięcie ujęcia i wykorzystanie wody zgromadzonej w zbiornikach wody czystej na terenie ZUW,

- wykorzystanie wody zgromadzonej w sieciowych zbiornikach wodociągowych,

- uruchomienie dostawy wody z alternatywnych źródeł,

- biomonitoring opierający się na organizmach wskaźnikowych (małże),

- układ wczesnego ostrzegania z wykorzystaniem stacji osłonowo-ostrzegawczej.

\section{Wyniki analizy ryzyka}

Szczegółowa analiza ryzyka pozwoliła na wytypowanie zdarzeń stanowiących największe zagrożenie dla jakości wody w źródle oraz ocenę skuteczności działania elementów systemu bezpieczeństwa. Zagrożenie o największym ryzyku w obszarze bezpieczeństwa konsumentów wody korzystających z SZZW objętego analizą stanowią zdarzenia niepożądane związane z sezonowymi zmianami jakości wody (zakwity wody, mętność, jon amonowy). Jeśli chodzi o zjawiska katastrofalne, to zagrożenie o największym ryzyku jest związane $\mathrm{z}$ awarią oczyszczalni ścieków (przepustowość $\mathrm{Q}=700 \mathrm{~m} / \mathrm{d}$ ) położonej na terenie strefy ochrony pośredniej ujęcia wody, w odległości ok. $4,8 \mathrm{~km}$ od ujęcia, tj. poniżej stacji osłonowo-ostrzegawczej. Prawdopodobieństwo zajścia takiego zdarzenia jest małe, jednak straty, które może ono spowodować wymagają skutecznego działania elementów systemu bezpieczeństwa. $\mathrm{W}$ tabeli 3 przedstawiono fragment przeprowadzonej analizy ryzyka. 
Tabela 3

Fragment analizy ryzyka dla wybranego ujęcia wody

\begin{tabular}{|c|c|c|}
\hline$=$ & $\begin{array}{l}\infty \\
\infty \\
\infty\end{array}$ & $\nabla$ \\
\hline 0 & in & $\nabla$ \\
\hline 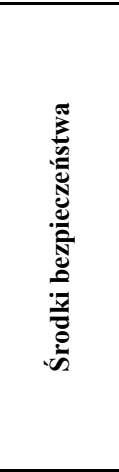 & 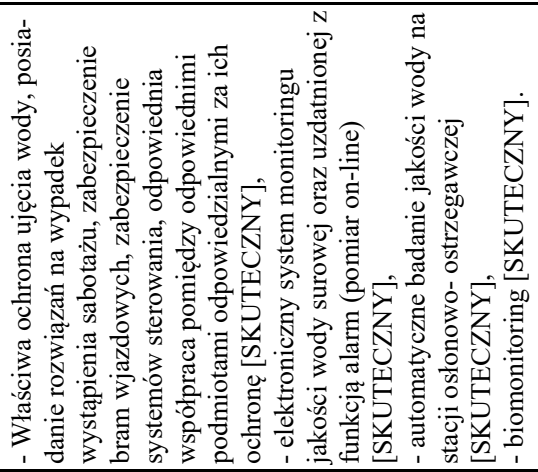 & 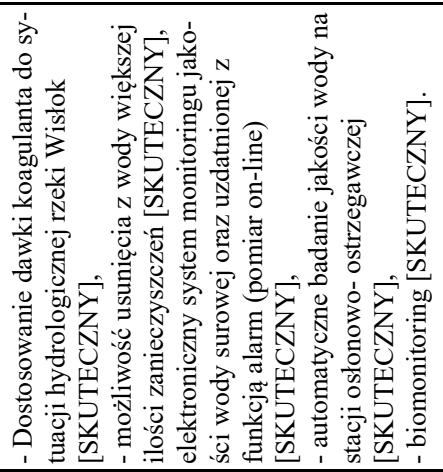 \\
\hline$a$ & - & $\nabla$ \\
\hline u & $\nabla$ & $\gamma$ \\
\hline 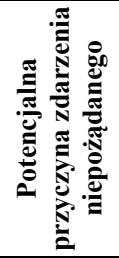 & 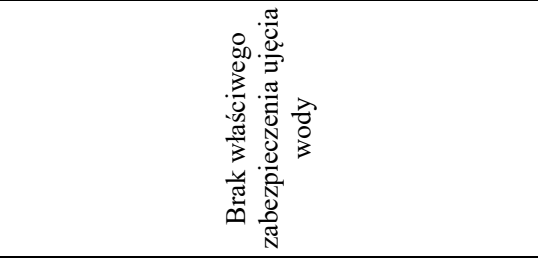 & 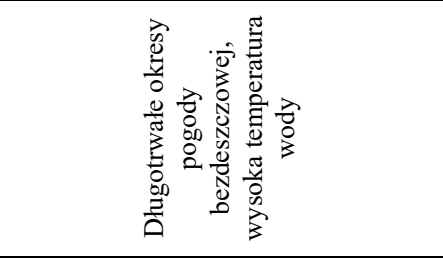 \\
\hline 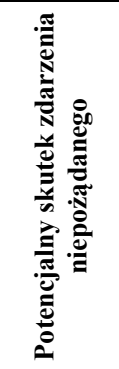 & 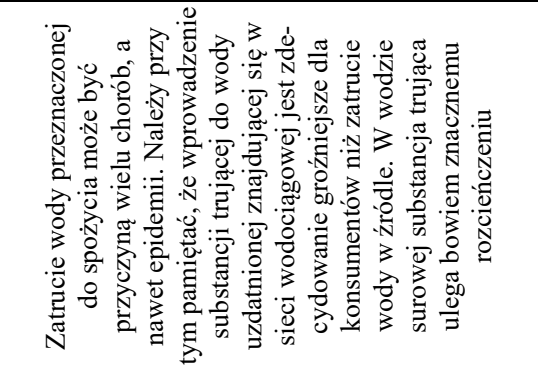 & 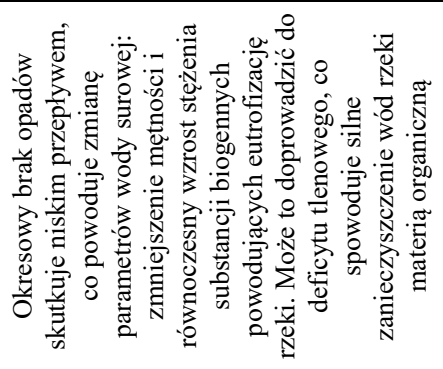 \\
\hline 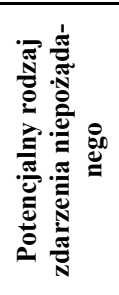 & 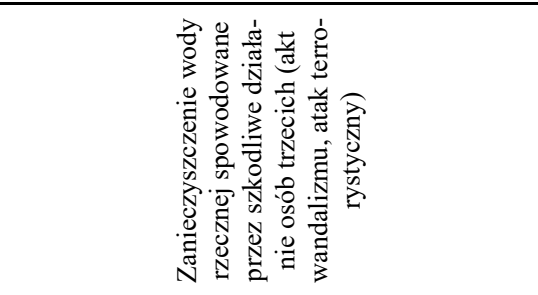 & 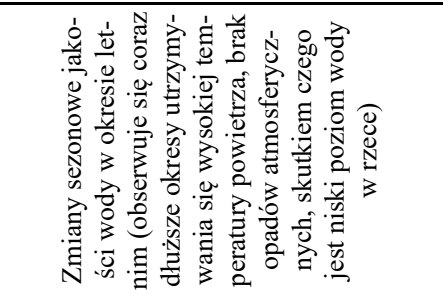 \\
\hline$\hat{\jmath}$ & - & $\alpha$ \\
\hline
\end{tabular}


Przedsiębiorstwo wodociągowe dysponuje dobrze zabezpieczonym SZZW przed czynnikami negatywnie wpływającymi na jakość ujmowanej wody, dlatego ryzyko dla analizowanych zdarzeń niepożądanych zostało ocenione jako tolerowane. W związku z tym proponuje się pozostawienie bez zmian zasięgu strefy ochrony bezpośredniej i pośredniej ujęcia wody.

Ocena ryzyka jest procesem ciągłym, dlatego na podstawie przeprowadzonej analizy przedstawiono propozycję działań korygujących lub naprawczych, jakie przedsiębiorstwo wodociągowe powinno podjąć w celu stałej kontroli i redukcji ryzyka.

Działania korygujące zostały przedstawione dla źródeł zagrożeń mających najistotniejszy wpływ na poziomy ryzyka generowanych zagrożeń:

- opracowanie procedur postępowania w przypadku wystąpienia zanieczyszczenia, którego konwencjonalny proces uzdatniania nie będzie w stanie usunąć,

- pozyskiwanie środków finansowych przez jednostki samorządu terytorialnego na budowę sieci kanalizacji sanitarnej w miejscowościach położonych na terenie zlewni rzeki Wisłok, w szczególności na terenie strefy ochrony pośredniej ujęcia wody,

- monitorowanie zużycia środków ochrony roślin na terenie ochrony pośredniej oraz kontrola ich jakości,

- opracowanie w oczyszczalniach ścieków planów kontroli stanu technicznego obiektów i rurociągów oraz wdrożenie procedur postępowania po rozpoznaniu poważnej awarii w oczyszczalniach ścieków położonych w zlewni rzeki Wisłok.

\section{Wnioski}

Analiza ryzyka dla ujęć wody powinna być gwarantem podejmowania właściwych decyzji, dotyczących wyboru najlepszych rozwiązań pod względem technicznym, ekonomicznym oraz eksploatacyjnym.

Badany system zbiorowego zaopatrzenia w wodę jest wyposażony w niezbędne zabezpieczenia związane z ujmowaniem wody z rzeki Wisłok. Ocena ryzyka zagrożeń dla ujęcia wody nie wykazała znaczących zagrożeń dla konsumentów wody wodociągowej.

Przedstawiona w pracy metodyka może być stosowana przez przedsiębiorstwo wodociągowe do corocznych ewaluacji zagrożeń ujęcia wody, czynników ryzyka bowiem nie można całkowicie wyeliminować.

Proponuje się pozostawienie bez zmian zasięgu strefy ochrony bezpośredniej i pośredniej ujęcia wody. Przeprowadzona analiza ryzyka obejmująca ocenę zagrożeń zdrowotnych z uwzględnieniem czynników negatywnie wpływających na jakość ujmowanej wody wykazała, że aktualna strefa ochrony bezpośredniej i pośredniej ujęcia wody jest wystarczająca, ale zarazem niezbędna dla spełnienia celu jakim jest dostawa do konsumentów wody w wymaganej ilości i pod odpowiednim ciśnieniem oraz dostawa wody w sposób ciągły i niezawodny, a także zapewnienie należytej jakości dostarczanej wody. 
W długoterminowej strategii rozwoju SZZW objętego analizą należy rozpatrzyć możliwość zaopatrzenia w wodę miasta z drugiego (alternatywnego) ujęcia wody.

\section{Literatura}

1. Lidzbarski M.: Analiza ryzyka w procesie ustanawiania strefy ochronnej ujęć wód podziemnych „Osowa” i „Dolina Radości” w Gdańsku. Biuletyn Państwowego Instytutu Geologicznego, vol. 475, Warszawa 2019.

2. Piegdoń I., Tchórzewska-Cieślak B.: The Use of Fuzzy Set Theory in Exploitation Management Process on the Water Supply Network. Journal of Konbin, No 3(35), Warszawa 2015, DOI 10.1515/jok-2015-0044.

3. Rak J., Boryczko K.: Assessment of water supply diversification using the Pielou index. Environmental Engineering V - Proceedings of the 5th National Congress of Environmental Engineering, Lublin 2017.

4. Rak J., Tchórzewska-Cieślak B.: Ryzyko w eksploatacji systemów zaopatrzenia w wodę. Wydawnictwo Seidel-Przywecki Sp. z o.o., Józefosław 2013.

5. Rak J., Żywiec J.: Selected Aspects of the Water Supply System Safety. Lecture Notes in Civil Engineering, vol. 47, 2020.

6. Rak. J., Tchórzewska-Cieślak B., Boryczko K., Szpak D.: Wykorzystanie zaawansowanych metod matrycowych $\mathrm{w}$ analizie ryzyka w systemach zbiorowego zaopatrzenia w wodę. Gaz, Woda i Technika Sanitarna, nr 11, Warszawa 2017.

7. Szpak D., Tchórzewska-Cieślak B.: The Use of Grey Systems Theory to Analyze the Water Supply Systems Safety. Water Resources Management, vol. 33, 2019.

8. Ustawa z dnia 20 lipca 2017 r. - Prawo wodne (Dz.U. 2017 poz. 1566 wraz z poźniejszymi zmianami).

9. Water safety plan manual: step-by-step risk management for drinking-water suppliers. WHO, Geneva 2009.

10. WIOŚ Rzeszów: Wody powierzchniowe województwa podkarpackiego. Identyfikacja wybranych zagrożeń. Rzeszów 2016.

11. Wniosek Dyrektywa Parlamentu Europejskiego i Rady w sprawie jakości wody przeznaczonej do spożycia przez ludzi (wersja przekształcona) z dnia 1.2.2018 r.

12. Zimoch I., Kuśnierski A.: Exploitation safety of water supply systems in areas used for agriculture. WIT Transactions on Ecology and the Environment, vol. 220, 2017. 